\title{
Identifikasi Nilai Piksel Sepanjang Garis Pantai di Teluk Genteng Menggunakan Citra Landsat 4-5 TM
}

\author{
INDRA ADRIANUS, N. M. R. RATIH CAHYA PERBANI, T. I. MARYANTO
}

\author{
Jurusan Teknik Geodesi \\ FTSP - Institut Teknologi Nasional, Bandung \\ Email: indraadrianus@gmail.com
}

\begin{abstract}
ABSTRAK
Teknologi pengindraan jauh memudahkan dalam penyediaan data untuk memperoleh garis pantai, terutama untuk wilayah lautan yang luas seperti Indonesia. Ekstraksi garis pantai dari citra satelit merupakan salah satu cara untuk memperoleh nilai-nilai piksel sepanjang garis pantai. Tujuan dari penelitian ini adalah mencari dan menentukan pola sebaran nilai piksel di sepanjang garis pantai area sampel di Teluk Genteng serta untuk mengetahui sinkronisasi dengan garis pantai dari Peta RBI. Penelitian ini menggunakan citra satelit Landsat 4-5 TM dengan Band 5 digunakan untuk memisahkan darat dan air. Pola sebaran nilai piksel didapatkan dengan menampalkan hasil ekstraksi dengan citra asli dan Peta RBI. Dari penelitian ini diperoleh bahwa pola sebaran nilai piksel batas yang terjadi pada area sampel menyebar secara acak, nilai piksel batas tertinggi adalah 242, nilai piksel batas terendah adalah 27, rentang nilai piksel batas adalah 215, rentang nilai piksel air adalah 126, rentang nilai piksel darat adalah 143, dan secara umum bentuk dari ekstraksi hampir mendekati garis pantai Peta $R B I$.
\end{abstract}

Kata kunci: ekstraksi garis pantai, nilai piksel, Peta RBI

\begin{abstract}
Technologies in remote sensing give the effortless way in preparing data to build the coastline, especially for country which has vast areas of sea such as Indonesia. Coastline extraction from satellite imagery is one of alternatives to get the pixel values along the coastline. To find and determine the distribution pattern of pixel values along the coastline of sampel area in Genteng Bay and to determine the synchronization with the coastline of RBI Map are taken as the focus of this research. Landsat 4-5 TM with Band 5 is the satellite imagery which is used to separate land and water. The distribution pattern of pixel values is obtained through overlaying the extraction with the initial pixel values and RBI Map. It can be detected that distribution of boundary pixel values in sampel area show the random pattern, the maximum values is 242, while the minimum is 27 with range of 215. The range of water pixel values is 126 and 143 for the land. Besides, the coastline extraction almost coincides with RBI Map coastline.
\end{abstract}

Keywords: extraction of coastline, pixel values, RBI Map 


\section{PENDAHULUAN}

Indonesia merupakan negara maritim dengan luas lautan mencapai 5,8 juta km2 dan memiliki 17.504 buah pulau dengan garis pantai sepanjang $104.000 \mathrm{~km}$ (Noegroho, 2013). Garis pantai diperlukan untuk menetapkan batas perairan teritorial dan manajemen kawasan pesisir. Dalam Peraturan Menteri Pekerjaan Umum Nomor 40 Tahun 2007, dinyatakan bahwa kawasan pesisir merupakan daerah peralihan antara ekosistem darat dan laut yang dipengaruhi oleh perubahan di darat dan di laut. Garis pantai merupakan salah satu cakupan dari wilayah pesisir yang memiliki definisi batas pertemuan antara bagian laut dan daratan pada saat terjadi air laut pasang tertinggi. Setiap wilayah pesisir suatu daerah memiliki garis pantai yang berbeda sehingga perlu untuk diketahui karakteristik dari suatu garis pantai pada suatu wilayah. Menurut Chand dan Acharya (dalam Kasim, 2012) informasi perubahan garis pantai sangat penting dalam berbagai kajian pesisir, misalnya rencana pengelolaan kawasan pesisir, perwilayahan bahaya, studi erosi-akresi, serta analisis dan pemodelan morfodinamik pantai. Rochaddi (2006) menyatakan bahwa permasalahan yang ada di Indonesia umumnya belum ditetapkannya batas wilayah pesisir baik dalam perencanaan maupun operasionalnya sehingga sampai sekarang wilayah pesisir masih diperlakukan sama seperti wilayah daratan lainnya.

Menurut Kasim (2010), integrasi teknik pengindraan jauh seperti penggunaan data Landsat TM terbukti menyediakan pendekatan yang sangat bermanfaat bagi studi-studi perubahan garis pantai. Pengukuran secara langsung akan membutuhkan waktu lama dan biaya yang cukup tinggi karena begitu luasnya wilayah Indonesia sehingga teknologi pengindraan jauh menjadi sebuah metode yang memudahkan untuk penyediaan data dinamika kawasan pesisir.

Penerapan teknologi pengindraan jauh dalam menentukan garis pantai yang telah diteliti adalah ekstraksi garis pantai. Menurut Alesheikh (2007), berbagai metode untuk ekstrak garis pantai dari citra sudah banyak dilakukan. Penelitian ekstraksi garis pantai sudah banyak dilakukan di luar maupun di dalam Indonesia, terutama di daerah kawasan pesisir yang memiliki bentang alam yang dinamis. Citra Landsat TM merupakan salah satu media pengindraan jauh yang dapat digunakan untuk untuk melakukan riset perubahan global, agrikultur, kehutanan, geologi, manajemen sumber daya, geografi, kualitas air dan oseanografi. Band 4, Band 5, dan Band 7 Citra Landsat TM merupakan citra inframerah yang memiliki kemampuan yang baik untuk memisahkan badan air dan darat. Pengalaman telah memperlihatkan bahwa citra inframerah Band 5 adalah band terbaik untuk ekstraksi darat dan air (Kelley, 1998 dalam Alesheikh, 2007) sehingga banyak digunakan untuk penelitian ekstraksi garis pantai. Lipakis (2008 dalam Kasim, 2012) menyatakan bahwa ekstraksi atau delineasi batas darat-laut menggunakan teknik pengindraan jauh data citra Landsat TM dapat meliputi beberapa pendekatan, yaitu interpretasi visual, teknik berbasis nilai spektral, komposit multi-data, serta analisis perubahan vektor. Sedangkan beberapa metode penajaman citra diantaranya spatial filtering, komposit RGB, rationing, klasifikasi, density slicing, metode BILKO, serta metode Algoritma AGSO (Australian Geological Surveys Oraganization) yang dikembangkan untuk memetakan citra perairan dangkal. Semua metode pendekatan penajaman citra tersebut berguna dalam membuat yang jelas darat-laut sehingga memudahkan untuk dijitasi (Hanifa, 2007 dalam Kasim, 2012). Metode ini menghasilkan ekstraksi garis pantai untuk delineasi secara efektif dan akurat berupa vektor. Delineasi adalah penggambaran fitur dengan mengidentifikasi dan membedakan fitur dari fitur lain di sekelilingnya dilanjutkan dengan menarik garis yang membatasi fitur tadi dari fitur lain di sekelilingnya (Kardono, 2012). 
Liu dan Jezek (2004) pada penelitiannya mengenai otomatisasi ekstraksi garis pantai dari citra satelit menggunakan pendekatan komprehensif untuk ekstrasi garis pantai secara efektif dan akurat menghasilkan algoritma untuk penentuan batas garis pantai dengan ketelitian hingga tingkat piksel. Pada penelitian ini informasi garis pantai di Teluk Genteng juga masih dalam tingkat piksel dengan menerapkan modifikasi Metode Liu dan Jezek (2004), namun tidak untuk otomatisasi melainkan untuk identifikasi nilai-nilai piksel batas garis pantai.

Garis pantai diperlukan untuk penetapan garis teritorial maupun manajemen wilayah pesisir. Dengan perkembangan teknologi pengindraan jauh memudahkan dalam penyediaan data untuk memperoleh garis pantai. Ekstraksi garis pantai dari citra satelit merupakan salah satu cara untuk memperoleh nilai-nilai piksel di sepanjang suatu garis pantai. Permasalahan dalam penelitian ini dapat dirumuskan sebagai berikut, yaitu: "Bagaimana pola sebaran nilai piksel di sepanjang garis pantai area sampel di Teluk Genteng dan bagaimana sinkronisasinya dengan garis pantai dari Peta RBI?"

Tujuan dari penelitian ini adalah mencari dan menentukan pola sebaran nilai piksel di sepanjang garis pantai area sampel di Teluk Genteng serta untuk mengetahui sinkronisasi dengan garis pantai dari Peta RBI. Sedangkan manfaat penelitian ini adalah dengan diketahuinya langkah awal berupa pola sebaran nilai piksel di sepanjang garis pantai diharapkan akan lebih memudahkan dalam otomatisasi ekstraksi garis pantai, terutama untuk wilayah lautan yang luas seperti Indonesia.

Pada penelitian ini permasalahan dibatasi pada hal-hal sebagai berikut: data yang digunakan adalah citra satelit Landsat 4-5 TM Band 5 pada tanggal 2 Juli Tahun 2005 dengan mode warna greyscale sudah dikoreksi, Peta RBI digunakan tahun 2000, pendekatan esktraksi garis pantai menggunakan metode thresholding, area sampel dibatasi sebesar 50x50 piksel mencakup wilayah pantai Teluk Genteng, dan ekstraksi garis pantai belum mempertimbangkan aturan mengenai garis pantai.

\section{METODOLOGI}

Daerah studi terletak di wilayah Kabupaten Sukabumi, Jawa Barat, tepatnya di Kecamatan Ciracap, Desa Gunungbatu. Secara geografis daerah studi terletak di antara $7^{\circ} 19^{\prime} 3,84^{\prime \prime}-7^{\circ}$ $26^{\prime} 6,14^{\prime \prime}$ LS dan $106^{\circ} 22^{\prime} 56,07^{\prime \prime}-106^{\circ} 30^{\prime} 54,16^{\prime \prime}$ BT. Lokasi daerah studi dapat dilihat pada Gambar 1.

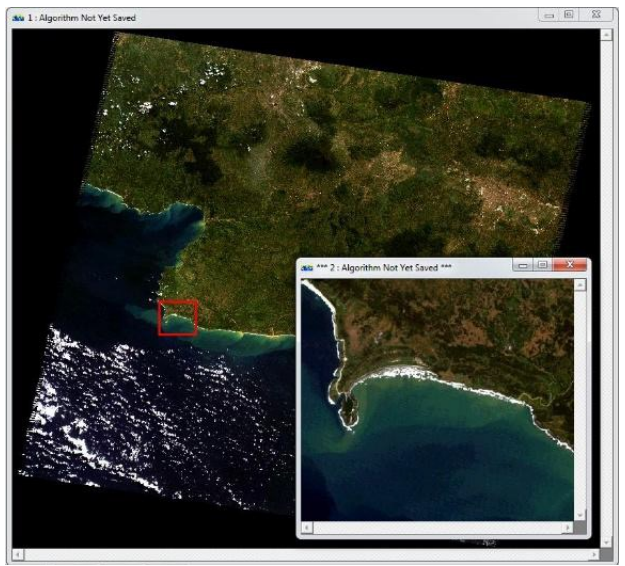

Gambar 1. Lokasi Daerah Studi (Sumber: USGS-NASA, 2005)

Reka Geomatika - 73 
Data yang digunakan pada penelitian ini terdiri dari Citra Landsat 4-5 TM dan Peta Rupa Bumi Indonesia (RBI) dengan deskripsinya dapat dilihat pada Tabel 1.

Tabel 1. Data Penelitian

\begin{tabular}{lll}
\hline Jenis Data & Deskripsi & \multicolumn{1}{c}{ Sumber } \\
\hline \multicolumn{3}{c}{ Data Utama } \\
\hline Landsat 4-5 & Batas Citra Path 122 - Row 65; & USGS-NASA* \\
TM & Resolusi spasial 30 m; 2 Juli 2005 \\
\hline \multicolumn{3}{c}{ Data Pendukung } \\
\hline Peta RBI & Skala 1:25.000 Lembar 1108-624 & Perpustakaan Museum \\
& Edisi I Tahun 2000 & Geologi, Bandung \\
\hline Keterangan: & & \\
* The United States Geological Survey - The National Aeronautics and Space Administration.
\end{tabular}

Data citra diunduh pada situs http://earthexplorer.usgs.gov/ yang dimiliki oleh USGS NASA. Cakupan data secara geografis berada di antara $6^{\circ} 19^{\prime} 32,55^{\prime \prime}-8^{\circ} 12^{\prime} 15,59^{\prime \prime}$ LS dan $105^{\circ}$ $50^{\prime} 39,49^{\prime \prime}-107^{\circ} 59^{\prime}$ 25,85" BT. Sistem proyeksi citra menggunakan UTM Zona $48 \mathrm{U}$ dengan datum WGS 84 dalam satuan meter. Data citra diproduksi dan dipublikasikan oleh USGSNASA. Citra Landsat dapat dilihat pada Gambar 2 dan Peta RBI dapat dilihat pada Gambar 3.

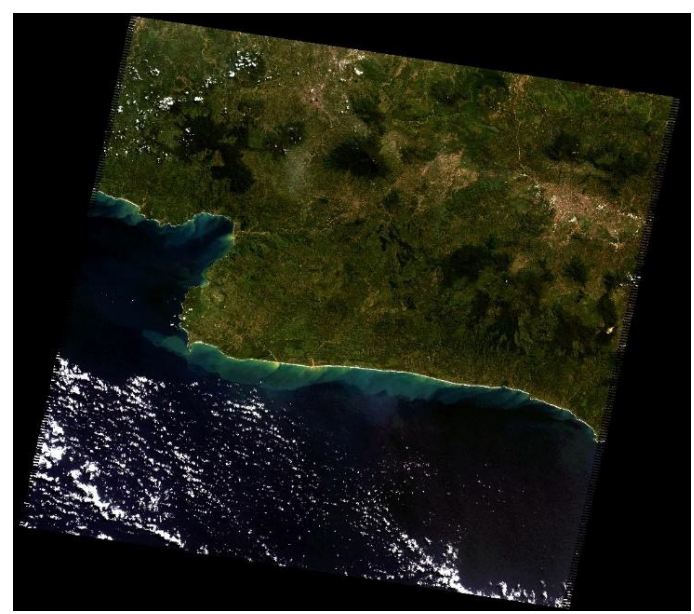

Gambar 2. Citra Landsat 4-5 TM Daerah Teluk Genteng Warna Alam (RGB:321)

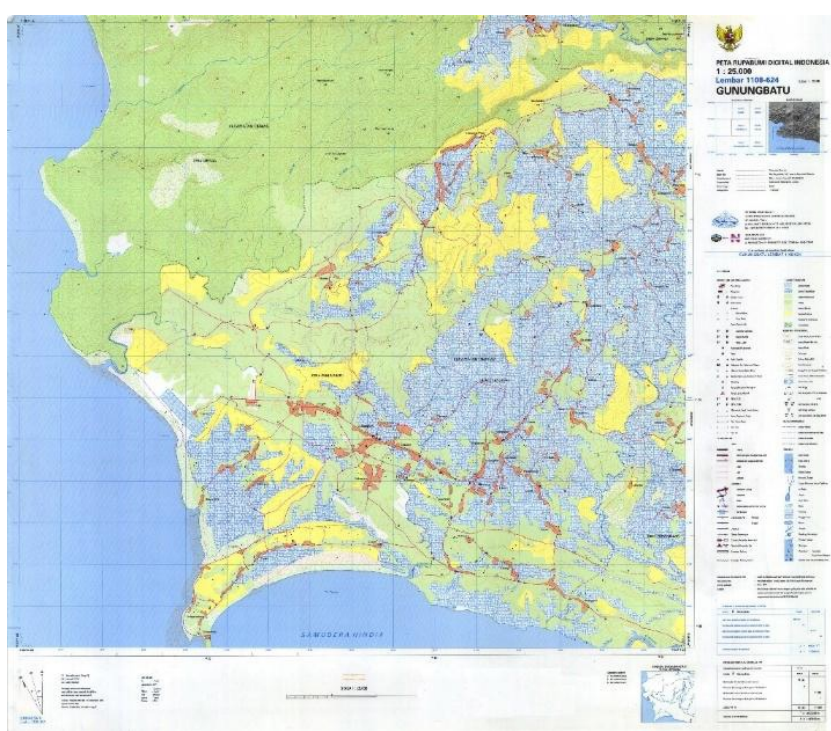

Gambar 3. Peta RBI Gunungbatu Tahun 2000

Reka Geomatika - 74 
Metodologi yang diterapkan pada penelitian untuk identifikasi nilai piksel sepanjang garis pantai di Teluk Genteng menggunakan citra Landsat 4-5 TM dapat dilihat pada Gambar 4.

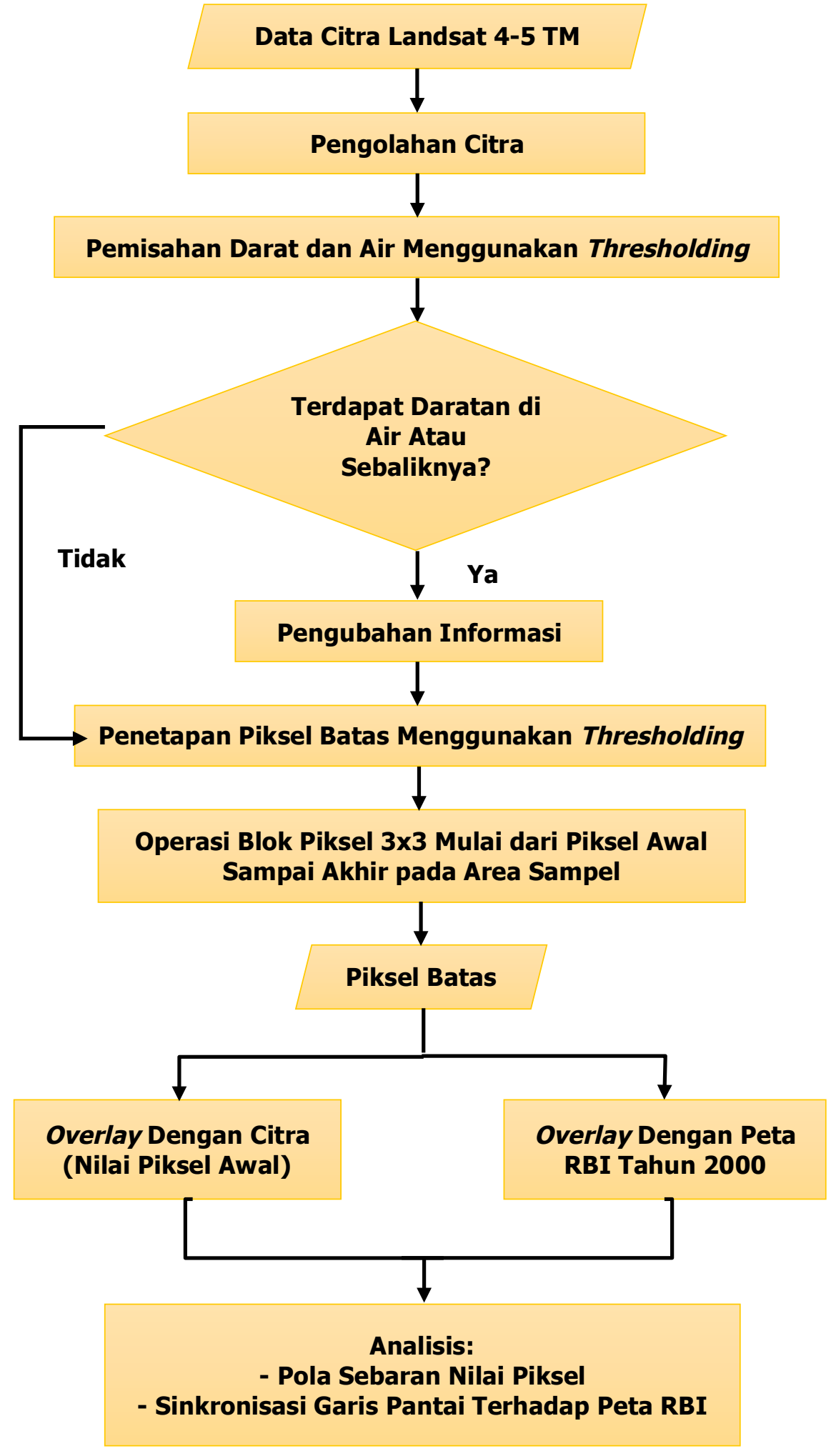

Gambar 4. Metodologi Penelitian 
Pengubahan informasi dimaksudkan supaya tidak terjadi adanya garis pantai di dalam daratan atau sebaliknya. Operasi blok piksel $3 \times 3$ yang diterapkan dalam menentukan arah vektor dan eliminasi piksel tetangga dalam pemilihan ini dengan modifikasi Metode Liu dan Jezek (2004), yaitu:

$b(i, j)=\{255$, if $g(i, j)=255$ and $(g(i-1, j)$, or $(g(i+1, j)$, or $(g(i, j-1)$, or $(g(i, j+1)=0) 0$, otherwise

\section{HASIL DAN PEMBAHASAN}

\subsection{Pengolahan Citra}

Pengolahan citra yang dihasilkan dari penelitian ini dapat dilihat pada Gambar 5. Menurut Kelley (1998 dalam Alesheikh, 2007), pengalaman telah menunjukkan bahwa dari enam band TM reflektif, band inframerah menengah lima adalah yang terbaik untuk mengekstraksi kenampakan antardarat-air dan garis pantai juga dapat diekstraksi dari single band citra di mana reflektansi air mendekati nol dalam reflektif band inframerah dan reflektansi darat semakin tinggi mendekati maksimum lebih baik dibandingkan air sehingga dalam proses pengolahan citra ini hanya menggunakan band 5 untuk memperoleh ekstraksi garis pantai.

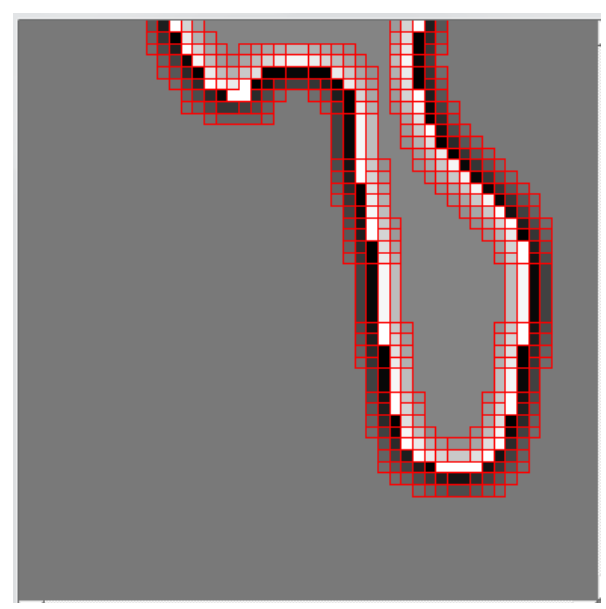

Gambar 5. Hasil Pengolahan Citra

Dalam penelitian ini citra telah terkoreksi, baik dengan koreksi geometrik maupun dengan koreksi radiometrik. Filter Gaussian 5x5 digunakan untuk penghalusan citra dan Filter Laplacian 5x5 untuk penajaman ujung tepi citra sebagai pengganti Filter Lee seperti yang diterapkan pada penelitian Liu dan Jezek (2004). Penggantian Filter Lee dilakukan karena filter tersebut digunakan untuk citra radar, sedangkan citra yang digunakan pada penelitan ini adalah citra satelit Landsat 4-5 TM. Penerapan thresholding dimaksudkan untuk membentuk nilai citra yang baru dari pemberian filter pada citra. Pemotongan citra 50x50 piksel dimaksudkan untuk membatasi area sampel yang diterapkan pada penelitian ini. Pembuatan vektor blok per piksel dimaksudkan untuk memudahkan dalam mengidentifikasi nilai piksel.

\subsection{Pemisahan Darat dan Air}

Pada penelitian ini pemisahan darat dan air dilakukan dengan memberikan label pada setiap vektor blok yang ada pada Gambar 6, dimana hasil dari pengolahan citra dilakukan dengan thresholding dengan nilai ambang yang diambil dari nilai mean pada citra tersebut. Pemisahan darat dan air ini dimaksudkan untuk mempermudah dalam mengidentifikasi piksel 
dimana yang berwarna putih adalah piksel darat dan yang berwarna hitam adalah piksel air. Adapun bentuk vektor blok yang memanjang mengindikasikan nilai piksel yang terdapat pada vektor blok tersebut sama.

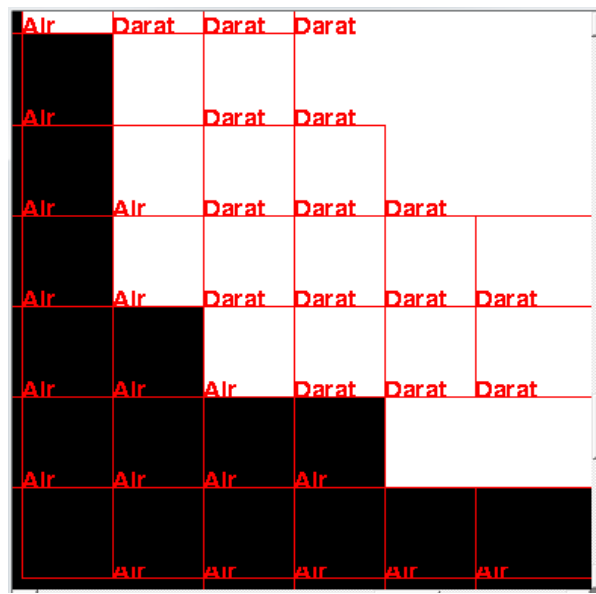

Gambar 6. Hasil Pemisahan Darat dan Air

\subsection{Pengubahan Informasi}

Ekstraksi piksel batas pantai dapat dilihat pada Gambar 7. Dalam penelitian ini tidak diperlukan pengubahan informasi pada area sampel dikarenakan tidak terdapat piksel darat yang dikelilingi oleh piksel air atau sebaliknya seperti pada Gambar 7. Namun, jika akan diterapkan pada area sampel lain terdapat piksel darat yang dikelilingi oleh piksel air atau sebaliknya, pengubahan informasi perlu dilakukan sehingga dalam memperoleh batas garis pantai akan terbentuk dengan baik.

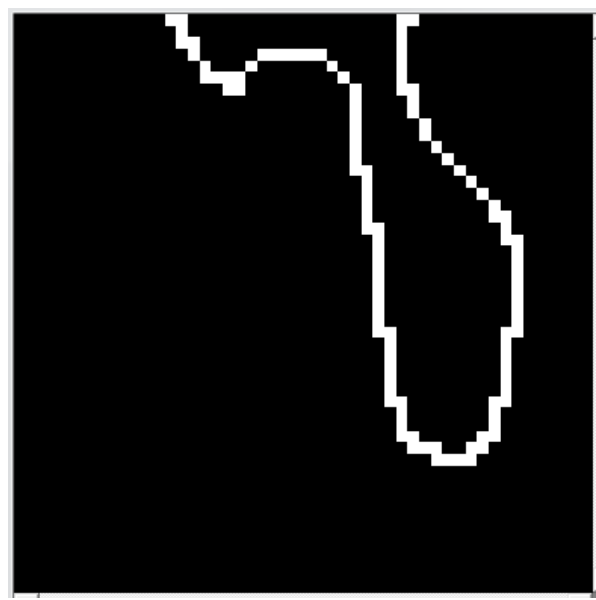

Gambar 7. Hasil Ekstraksi Piksel Batas

\subsection{Pola Sebaran Nilai Piksel}

\subsubsection{Pola Sebaran Nilai Piksel pada Piksel Batas}

Nilai piksel didapat dari hasil ekstraksi batas di area sampel di Teluk Genteng berdasarkan Citra Landsat 4-5 TM 2 Juli 2005 yang ditampalkan pada citra asli dimaksudkan untuk mengidentifikasi pola sebaran nilai piksel yang menjadi piksel batas. Nilai piksel batas di area sampel dapat dilihat pada Gambar 8. 


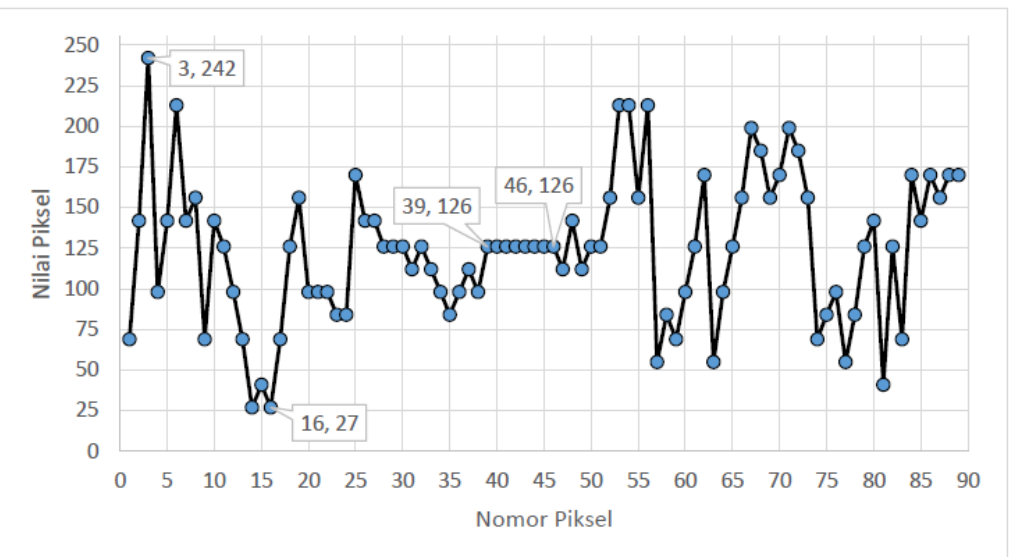

\section{Gambar 8. Nilai Piksel Ekstraksi Batas Pada Citra Awal}

Nilai piksel tertinggi, yaitu 242 terdapat pada posisi piksel batas ketiga, sedangkan untuk nilai piksel terendah, yaitu 27 pada posisi piksel batas ke-16. Piksel tertinggi dan terendah berada pada pantai barat ke arah utara seperti dapat dilihat pada Gambar 9(a) dan 9(b). Dengan demikian rentang nilai piksel di area sampel bernilai 215. Dari informasi nilai-nilai piksel di sepanjang pantai area sampel, terlihat bahwa nilai-nilai piksel pada Gambar 8 memiliki tidak keteraturan di dalam pola sebarannya. Nilai-nilai tersebut menyebar dengan sifat yang lebih acak. Fluktuasinya tidak mengindikasikan adanya fenomena yang berulang. Di sini keteraturan hanya ditemukan di pantai barat ke arah selatan, ada sejumlah piksel berurutan yang memiliki nilai yang sama yang dimana membentuk pola linear. Nilai piksel tersebut terdapat pada nomor piksel ke-39 sampai ke-46 seperti dapat dilihat pada Gambar 9(c) dan 9(d).

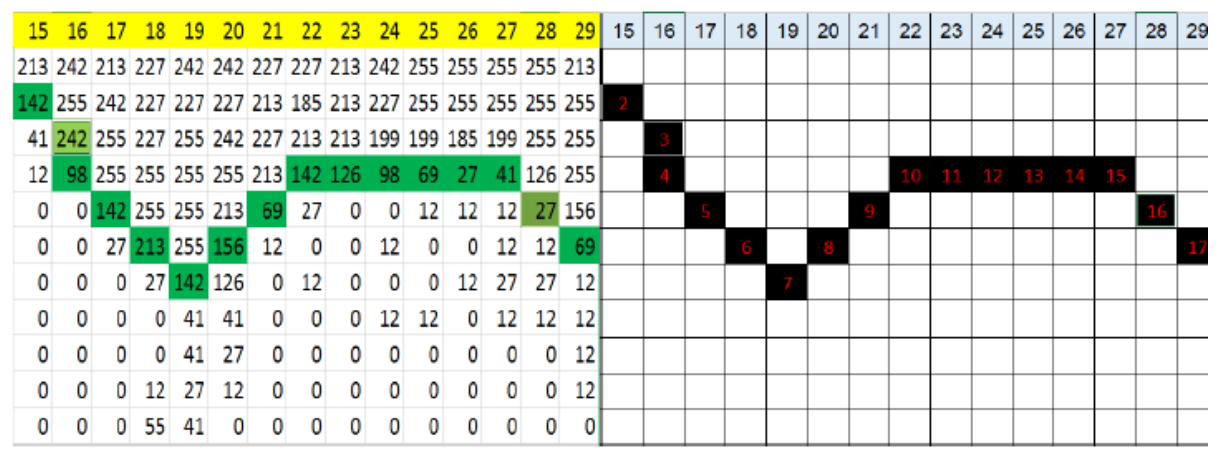

(a). Nilai Piksel Tertinggi dan Terendah

$$
\begin{array}{|r|r|r|r|r|r|r|}
\hline 0 & 27 & 98 & 112 & 126 & 142 & 142 \\
\hline 0 & 27 & 84 & 126 & 126 & 126 & 156 \\
\hline 0 & 27 & 84 & 126 & 126 & 126 & 126 \\
\hline 0 & 12 & 84 & 126 & 126 & 126 & 112 \\
\hline 0 & 12 & 69 & 126 & 126 & 126 & 142 \\
\hline 0 & 12 & 69 & 126 & 142 & 126 & 126 \\
\hline 0 & 0 & 55 & 126 & 126 & 142 & 142 \\
\hline 0 & 0 & 27 & 98 & 126 & 126 & 126 \\
\hline 0 & 0 & 0 & 69 & 126 & 142 & 126 \\
\hline 0 & 0 & 0 & 55 & 112 & 142 & 126 \\
\hline
\end{array}
$$

(๖. Nilai Piksel Membentuk Pola Linear (b). Nomor Piksel Tertinggi dan Terendah

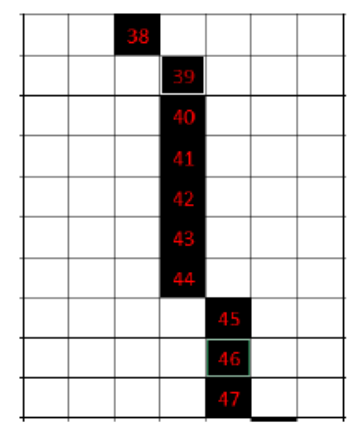

(d). Nomor Piksel Membentuk Pola Linear

Gambar 9. Nilai Piksel dan Nomor Piksel 


\subsubsection{Pola Sebaran Nilai Piksel Pada Tetangga Piksel Batas}

Pola sebaran nilai piksel pada tetangga piksel batas dapat dilihat pada Gambar 10, dimana yang berwarna hijau merupakan piksel batas, yang berwarna orange merupakan tetangga terluar dari piksel batas atau yang dianotasikan sebagai air dan yang berwarna biru merupakan tetangga bagian dalam dari piksel batas atau yang dianotasikan sebagai darat. Adapun nilai piksel tertinggi dari tetangga terluar adalah 126 dan nilai piksel terendah dari tetangga terluar adalah nol sehingga range diperoleh 126 . Untuk nilai piksel tertinggi dari tetangga terdalam adalah 255 dan nilai piksel terendah dari tetangga terdalam adalah 112 sehingga range diperoleh 143.

\begin{tabular}{|c|c|c|c|c|c|c|c|c|c|c|c|c|}
\hline 227 & 227 & 213 & 185 & 213 & 227 & 255 & 255 & 255 & 255 & 255 & 255 & 242 \\
\hline 255 & 242 & 227 & 213 & 213 & 199 & 199 & 185 & 199 & 255 & 255 & 255 & 255 \\
\hline 255 & 255 & 213 & 142 & 126 & 98 & 69 & 27 & 41 & 126 & 255 & 255 & 255 \\
\hline 255 & 213 & 69 & 27 & 0 & 0 & 12 & 12 & 12 & 27 & 156 & 255 & 255 \\
\hline 255 & 156 & 12 & 0 & 0 & 12 & 0 & 0 & 12 & 12 & 69 & 156 & 170 \\
\hline 142 & 126 & 0 & 12 & 0 & 0 & 0 & 12 & 27 & 27 & 12 & 126 & 142 \\
\hline 41 & 41 & 0 & 0 & 0 & 12 & 12 & 0 & 12 & 12 & 12 & 156 & 213 \\
\hline
\end{tabular}

$\square$ Piksel Tetangga Terluar, $\square$ Piksel Batas, $\square$ Piksel Tetangga Terdalam

Gambar 10. Pola Sebaran Nilai Piksel Tetangga Piksel Batas

\subsection{Sinkronisasi Piksel Batas Dengan Garis Pantai pada Peta RBI}

Pada Gambar 11 dapat dilihat hasil overlay vektor piksel batas dengan Peta RBI di area sampel di Teluk Genteng dimana yang berupa vektor blok adalah hasil ekstraksi piksel batas dengan dianotasikan menggunakan vektor blok. Garis yang dilalui oleh vektor blok adalah garis pantai Peta RBI.

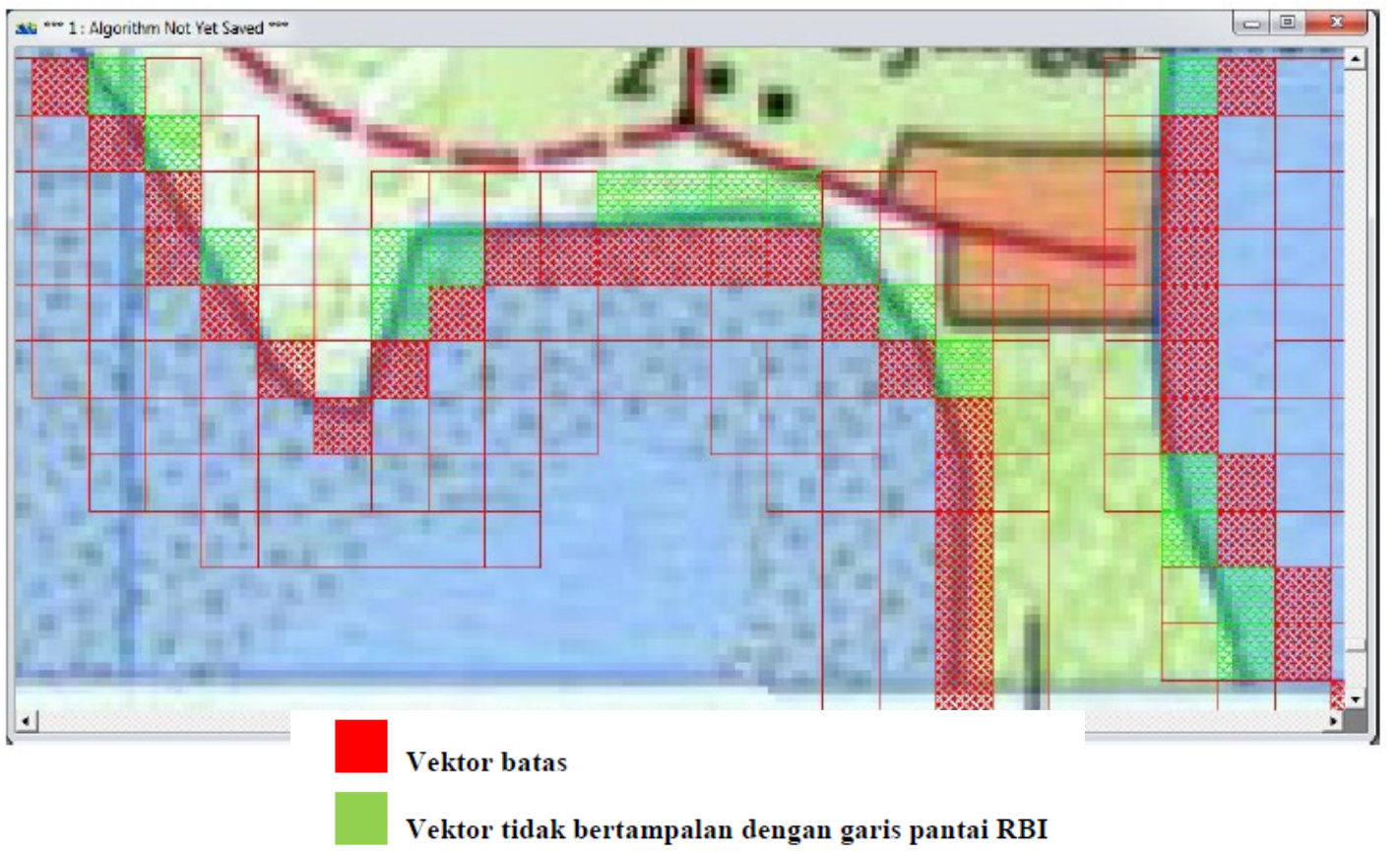

Gambar 11. Overlay Vektor Blok dengan Peta RBI 
Maksud dari overlay vektor dengan RBI adalah untuk melihat sinkronisasi antara piksel batas dengan garis pantai RBI. Secara umum bentuk dari ekstraksi hampir mendekati garis pantai Peta RBI. Terdapat beberapa piksel yang tidak sinkron dengan garis pantai RBI, terutama terjadi pada lokasi pembelokan.

Dilihat dari jumlah vektor blok yang ada pada Gambar 11 dapat dihitung persentase vektor blok yang tidak dilalui oleh garis pantai Peta RBI sebesar $21 \%$ dimana penyimpangan terbesarnya sejauh satu piksel, yaitu 30 meter. Kemungkinan yang menyebabkan penyimpangan salah satunya terjadi oleh pasang surut laut di mana data citra yang diperoleh tidak multitemporal. BSNI (2010) menyatakan bahwa garis pantai pada pada peta RBI merupakan garis pantai pada saat air pasang rata-rata dan garis pantai yang digambarkan berupa suatu area sehingga dapat diasumsikan bahwa piksel yang tidak dilalui bisa disebabkan oleh citra diambil tidak pada saat air laut sedang pasang. Penyebab lainnya bisa disebabkan ada perubahan garis pantai karena data citra yang digunakan memiliki perbedaan waktu lima tahun, yaitu antara Tahun 2000 dan 2005. Waktu pengukuran peta RBI yang digunakan adalah Tahun 1998 sehingga rentang waktu antara data citra dengan Peta RBI sebenarnya adalah tujuh tahun.

\section{KESIMPULAN DAN SARAN}

\subsection{Kesimpulan}

Kesimpulan yang dapat diambil berdasarkan identifikasi nilai piksel sepanjang garis pantai di Teluk Genteng menggunakan Citra Landsat 4-5 TM adalah sebagai berikut: pola sebaran nilai piksel yang terjadi pada area sampel menyebar secara acak; nilai piksel tertinggi pada sebaran piksel yang menjadi piksel batas, yaitu 242 dan nilai piksel terendah adalah 27 sehingga rentang nilai piksel di area sampel bernilai 215; nilai piksel tertinggi pada sebaran piksel air yang menjadi tetangga piksel batas, yaitu 126 dan nilai piksel terendah adalah nol sehingga rentang nilai piksel terluar bernilai 126; nilai piksel tertinggi pada sebaran piksel darat yang menjadi tetangga piksel batas batas, yaitu 255 dan nilai piksel terendah adalah 112 sehingga rentang nilai piksel terluar bernilai 143; secara umum bentuk dari ekstraksi hampir mendekati garis pantai Peta RBI; persentase piksel yang tidak dilalui garis pantai RBI sebesar $21 \%$ dimana penyimpangan terbesarnya sejauh satu piksel, yaitu 30 meter.

\subsection{Saran}

Beberapa saran mengenai hal-hal yang masih diperlukan untuk lebih meningkatkan kualitas identifikasi nilai piksel sepanjang garis pantai, di antaranya: dalam ekstraksi pantai dari citra seharusnya mengetahui waktu yang terjadi pada akuisisi data sehingga dapat memperhitungkan pasut; penggunaan citra yang memiliki resolusi tinggi sehingga piksel yang merepresentasikan garis pantai mendekati garis pantai sesungguhnya; dalam ekstraksi piksel batas seharusnya sudah menerapkan aturan penentuan garis pantai; citra yang digunakan sebaiknya multitemporal, dan Peta RBI juga memiliki masa pembuatan yang sama. 


\section{DAFTAR PUSTAKA}

Alesheikh, A. A., A. Ghorbanali, N. Nouri. (2007). Coastline Change Detection Using Remote Sensing. Int JEnvironSci Tech, 4(1): 61-66.

BSNI (2010). Spesifikasi Penyajian Peta Rupa Bumi Bagian 2 Skala 1:25.000. Dipetik dari: http://www.big.go.id/assets/download/sni/SNI/18.\%20SNI\%206502.2-2010\%20 Spesifikasi\%20penyajian\%20peta\%20rupa\%20bumi\%2025.000.pdf pada tanggal 8 Januari 2016.

Kardono, P. (2012). Standard Operating Procedures Tentang Pemktahiran Peta Sistem Lahan. Deputi Informasi Geospatial Tematik, BIG.

Kasim, F. (2010). Laju Perubahan Garis Pantai Mengguakan Modifikasi Teknik Single Transect (ST) dan Metode End Point Rate (EPR): Studi Kasus Pantai Sebelah Utara Indramayu-Jawa Barat. Pengajar Program Studi Manajemen Sumberdaya Perairan, Fakultas Pertanian UNG.

Kasim, F. (2012). Pendekatan Beberapa Metode dalam Monitoring Perubahan Garis Pantai Menggunakan Dataset Pengindraan Jauh Landsat dan SIG. Program Studi Manajemen Sumberdaya Perairan, Fakultas Pertanian UNG.

Liu, H. dan K. C. Jezek. (2004). Automated Extraction Of Coastline From Satellite Imagery by Integrating Canny Edge Detection and Locally Adaptive Thresholding Methods. International Journal of Remote Sensing, Taylor \& Francis Ltd. Dipetik 8 Januari 2016 dari: http://www.tandf.co.uk/journals.

Noegroho, A. (2013). Keanekaragaman Hayati Laut Indonesia Terbesar Di Dunia. Pusat Data Statistik dan Informasi Kementrian Kelautan dan Perikanan, Jakarta Pusat.

Peraturan Menteri Pekerjaan Umum Nomor 40 Tahun 2007 tentang Pedoman Perencanaan Tata Ruang Kawasan Reklamasi Pantai.

Rochaddi, B. (2006). Delineasi Batas Biogeofisik Wilayah Daratan Pesisir. Laboratorium Geologi Kelautan, Jurusan Ilmu Kelautan, FPIK UNDIP.

USGS. (2015). Landsat Processing Details. Dipetik 8 Januari 2016 dari: https://Ita.cr.usgs.gov/TM. 